\title{
SEROPREVALENCE OF HUMAN TOXOCARIASIS IN ANDEAN COMMUNITIES FROM THE NORTHEAST OF LIMA, PERU
}

Yrma A. ESPINOZA(1), Pedro E. HUAPAYA(1,3), William H. ROLdÁN(1), Susana JIMÉNEZ(1), Enma P. ABANTO(1), Carlos A. ROJAS(1), Yuri A. CAVERO(1) \& César A. GUTIÉRREZ(2)

\begin{abstract}
SUMMARY
The aim of this study was to assess the seroprevalence of human toxocariasis in three Andean communities from the Northeast of Lima, Peru. A total of 303 subjects including children and adults were studied and blood samples were collected to detect anti-Toxocara antibodies by ELISA-IgG test and by hematological examination; stool samples were collected also for parasitological examination. The overall seroprevalence of toxocariasis observed in the total population was $20.46 \%$, with a significant high proportion in children from one to 10 years old $(p=0.034)$. Among the subjects with positive serology, $32.26 \%$ of them had respiratory disturbances, $22.58 \%$ hepatomegaly, $17.74 \%$ ocular signs or symptoms, $14.51 \%$ abdominal pain, $9.68 \%$ neurological involvement, and $4.84 \%$ cutaneous signs, but none of these clinical features were associated to a positive serology by multivariate analysis. Furthermore, $79.03 \%$ of seropositive subjects also harbored at least one intestinal parasite, which was associated to a positive serology $(\mathrm{p}<0.05)$. The presence of pets within the houses, a previous history of pica or geophagia and the use of public places were also present in this population, but only the latter was associated to the serology $(\mathrm{p}<0.05)$. In conclusion, clinical, serological, and epidemiological evidences for larval Toxocara infection were found in the studied population.
\end{abstract}

KEYWORDS: Seroprevalence; Toxocariasis; Andean communities; Risk factors; Peru.

\section{INTRODUCTION}

Human toxocariasis is a helminthozoonosis due to the infection by larval stages of the Toxocara canis or T. cati, a common roundworm of dogs and cats, respectively. The adult worms live in the upper intestinal tract of their definitive hosts and can produce over 200,000 eggs per day which are excreted to the environment in their feces ${ }^{5,15}$. Toxocara eggs usually become infective after three or five weeks and have been isolated in backyard soil, parks, playgrounds, and other public places around the world ${ }^{5,15}$.

Humans become infected by ingesting embryonated Toxocara eggs from soil, dirty hands, and raw vegetables, but also when they ingest poor-cooked animal tissues containing infective larvae. In all cases, the larvae are released into the gut and then, penetrate the small intestine, enter the circulatory system, and invade several organs such as liver, heart, lungs, eyes, brain, and other tissues. Its migration causes an intense inflammatory response and eosinophilia ${ }^{15,17}$.

Visceral larva migrans (VLM) and ocular toxocariasis (OT) are the two main clinical forms recognized in the literature. VLM or visceral toxocariasis (VLM) is characterized mainly by fever, hepatomegaly, splenomegaly, respiratory disorders, hypergammaglobulinemia and eosinophilia; OT is the result after the larval invasion to the eye and their pathological effects include leucocoria, chorioretinitis, optic papillitis, endophthalmitis, and can lead to a partial or complete loss of vision ${ }^{5,15,17}$.

The large discrepancy among the relative small number of reported cases of VLM and OT and the high rates of seroprevalence, led to a search for other clinical manifestations for Toxocara infections. Other forms of toxocariasis have been recognized with milder and even less specific signs. They have been termed as 'common toxocariasis' in adults and 'covert toxocariasis' in children ${ }^{15,17}$.

Because of the difficulty of detecting Toxocara larvae in biopsy tissues, the diagnosis of human toxocariasis is essentially based on immunological tests, and the method of choice is the ELISA test using the excretory-secretory antigens of infective larvae of Toxocara canis (TES) $)^{11,12}$. With the development of this test, seroepidemiological studies also have been possible $e^{5,15}$.

Human infection with larval stages of Toxocara is higher in tropical and developing countries, where this zoonosis usually is associated with low socioeconomic levels. The rate ranged from $1 \%$ in $\operatorname{Spain}^{18}$ to $86 \%$ in Saint-Lucia ${ }^{25}$; from $3.6 \%$ to $24.7 \%$ in Brazil ${ }^{2,4}$; $47.5 \%$ in Colombia ${ }^{1}$; from $34.9 \%$ to $66.6 \%$ in Venezuela ${ }^{9,14}$, and from $37.9 \%$ to $39 \%$ in Argentina ${ }^{3,19}$.

(1) Sección de Parasitología, Instituto de Medicina Tropical "Daniel A. Carrión”, Facultad de Medicina, Universidad Nacional Mayor de San Marcos, Callao, Perú.

(2) Sección de Epidemiología, Instituto de Medicina Tropical "Daniel A. Carrión”, Facultad de Medicina, Universidad Nacional Mayor de San Marcos, Callao, Perú.

(3) Dirección de Atención Integral de Salud - Dirección Regional de Salud Lima. Edificio Las Terrazas, Malecón Roca s/n, Huacho, Perú.

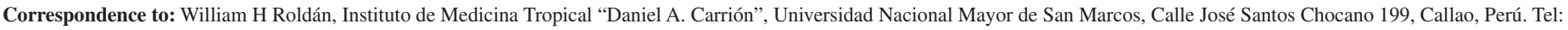
+511-4521742. E-mail: willyroldan23@ hotmail.com 


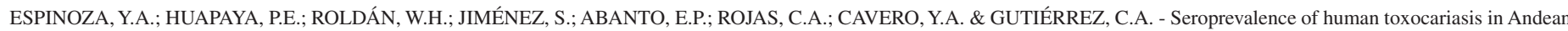
communities from the northeast of Lima, Peru. Rev. Inst. Med. Trop. São Paulo, 52(1): 31-36, 2010.

In Peru, recent reports indicate frequencies from $7.8 \%$ to $32.4 \%$ in rural populations from different places and $40 \%$ in subjects with ocular suspicion $^{7,8,13,21}$. However, seroepidemiological studies about toxocariasis in Peruvian Andean populations have not been reported.

The aim of this survey was to assess the seroprevalence of human Toxocara infection and toxocariasis in three Andean districts in the province of Canta, Department of Lima, Peru, look for the risk factors for this infection, and to study any possible association with the observed clinical features.

\section{SUBJECTS, MATERIALS AND METHODS}

Study population and subject selection: This study was carried out from March to August 2007, in the Andean rural communities of Cullhuay, Lachaqui, and El Olivar from the province of Canta (Latitude $11^{\circ} 24^{\prime} 12^{\prime \prime} \mathrm{S}$ and Longitude $76^{\circ} 31^{\prime} 42^{\prime \prime} \mathrm{W}$ ), which is located $122 \mathrm{~km}$ from the Northeast of Lima city. These places have a mean temperature of $14{ }^{\circ} \mathrm{C}$ and an average relative humidity of $88 \%$. A detailed description of these communities is presented in the Table 1.

People living in these communities are considered to be in the poorest socioeconomic condition, working in agriculture, livestock and fishing. From this background, a total of 303 subjects from one to 88 years old accepted to participate in this study, after their agreement for this study.

A baseline questionnaire (including an informed consent) was applied to all participants and the following clinical data were registered: anamnesis data, clinical signs and symptoms (pulmonary infiltrates, bronchospasms, bronchitis, hepatosplenomegaly, abdominal pain, leucocoria, strabismus, retinitis, visual loss, convulsions and other signs of central nervous system involvement, pruritus and chronic weakness); epidemiological data and risk factors, including age, sex, ownership of dogs or/and cats, their presence at home, use of public places (i.e. central squares and public parks), history of pica and/or geophagia. This research had the approval of the Ethical Research Committee of the Institute of Tropical Medicine, UNMSM.

Collection of samples: Blood samples were collected in vacutainer tubes with EDTA as anticoagulant for hematological purposes. In order to obtain sera for immunoserological purposes, blood samples were collected in vacutainer tubes without anticoagulant, separated, and stored at $-20^{\circ} \mathrm{C}$ until use. For parasitological examination, stool samples were freshly collected and then preserved by mixing vol:vol with a solution of $10 \%$ formalin in physiological saline and stored at room temperature until their use.
Immunoserology: Anti-Toxocara IgG antibodies were detected in serum samples by an in-house ELISA-IgG test (100\% sensitivity and $90 \%$ specificity) and each serum sample was previously absorbed with total Ascaris suum adult extract in order to diminish any cross-reactivity in the immunoassay ${ }^{20}$. All sera samples were tested at 1:200 dilutions and all stages of the immunoassay were performed at room temperature. The cut-off was set by the mean optical density (OD) of the negative reference serum, plus three times standard deviations. Serum samples with OD above of cut-off value were considered as positive. Additionally, all positive sera were then serially two-fold diluted to determine the relative antibody concentration by titration (inverse of the dilution).

Hematological examination: It included total hemoglobin, hematocrit, total leukocyte count, and leukocyte differential formula. Total hemoglobin was performed using a kit (Wiener Lab, Argentina); the hematocrit was performed using the microhematocrit method in capillary tubes $^{16}$. Total leukocyte count was obtained by direct microscopic observation in a Neubauer chamber; leukocyte differential formula was obtained by stained-blood smear with Wright-Giemsa stain. Leukocytosis was defined as cell count more than 10,000 cells/ $\mu \mathrm{L}$ and the eosinophilia was defined as absolute eosinophils count more than 500 cells $/ \mu \mathrm{L}$ and classified by percentage as normal $(<6 \%)$, mild $(6-10 \%)$, moderate $(11-$ $15 \%)$, and severe $(>15 \%)$ eosinophilia ${ }^{16,26}$.

Coproparasitological examination: It was realized by direct microscopic observation in fecal smears and by rapid sedimentation technique to detect parasites that can generate cross-reactivity with the serological test ${ }^{9,21}$.

Data analysis: All data were introduced on an Excel spreadsheet and a statistical analysis was performed using the program SPSS 15.0. Bivariate analysis, Chi-square test or Fisher's exact test and Odds Ratio (OR) were performed in order to confirm the mean differences between groups. In order to find some evidence of association among the different variables, two logistic regression models were estimated and adjusted by sex and age, one for the clinical data and the other one for risk factors, taking into account all the variables that were found with $\mathrm{p}<0.10$ in the bivariate analysis. A p value $<0.05$ was always considered as significant in all cases.

\section{RESULTS}

From a total population of 303 subjects (128 male and 175 female), 62 subjects were found positive by ELISA-IgG, giving an overall of $20.46 \%$ seroprevalence. From 62 subjects with a positive serology result, $80.65 \%$ had a titer at 200 and only $19.35 \%$ had a titer at 400 . None of the seropositive subjects had titers greater than 400 .

Table 1

Geographic and population data of the three Andean communities from the province of Canta, Peru, 2007

\begin{tabular}{|c|c|c|c|c|c|c|}
\hline \multirow{2}{*}{ Community } & \multirow{2}{*}{ District home } & \multicolumn{3}{|c|}{ Geographic data } & \multicolumn{2}{|c|}{ Population data } \\
\hline & & Latitude & Longitude & Mean altitude* & No. Residents ${ }^{\mathrm{a}}$ & No. Participants ${ }^{b}$ \\
\hline Cullhuay & Huaros & $11^{\circ} 24^{\prime} 11.38^{\prime \prime} \mathrm{S}$ & $76^{\circ} 31^{\prime} 43.51^{\prime \prime} \mathrm{W}$ & 3630 & 412 & 130 \\
\hline Lachaqui & Lachaqui & $11^{\circ} 33^{\prime} 28.62^{\prime \prime} \mathrm{S}$ & $76^{\circ} 37^{\prime} 57.80^{\prime \prime} \mathrm{W}$ & 3450 & 842 & 50 \\
\hline El Olivar & Canta & $11^{\circ} 28^{\prime} 08.90^{\prime \prime} \mathrm{S}$ & $76^{\circ} 37^{\prime} 23.59^{\prime \prime} \mathrm{W}$ & 2825 & 727 & 120 \\
\hline
\end{tabular}

$*=$ meters above sea level; ${ }^{\mathrm{a}}=$ estimated according to the census in $2006 ;{ }^{\mathrm{b}}=$ Number of people who finally had agreed to participate in this study. 


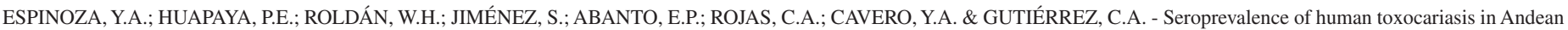
communities from the northeast of Lima, Peru. Rev. Inst. Med. Trop. São Paulo, 52(1): 31-36, 2010.

Table 2

Seroprevalence of anti-Toxocara antibodies according to the age in three Andean communities from the province of Canta, Peru, 2007

\begin{tabular}{|c|c|c|c|c|c|c|c|c|c|c|c|c|}
\hline \multirow{3}{*}{ Community } & \multicolumn{10}{|c|}{ Age groups } & \multirow{3}{*}{ Total } & \multirow{3}{*}{$\%$ Seropositive } \\
\hline & \multicolumn{2}{|c|}{1 to 10} & \multicolumn{2}{|c|}{11 to 20} & \multicolumn{2}{|c|}{21 to 40} & \multicolumn{2}{|c|}{41 to 60} & \multicolumn{2}{|c|}{61 to 88} & & \\
\hline & Pos* & $\mathrm{Neg}$ & Pos & $\mathrm{Neg}$ & Pos & $\mathrm{Neg}$ & Pos & $\mathrm{Neg}$ & Pos & $\mathrm{Neg}$ & & \\
\hline Cullhuay & 10 & 36 & 9 & 19 & 5 & 31 & 2 & 13 & 1 & 4 & 130 & 20.77 \\
\hline El Olivar & 8 & 23 & 1 & 41 & 5 & 35 & 1 & 5 & 0 & 1 & 120 & 12.50 \\
\hline Lachaqui & 9 & 12 & 4 & 6 & 6 & 13 & 1 & 0 & 0 & 2 & 53 & 37.74 \\
\hline Total & 27 & 71 & 14 & 66 & 16 & 79 & 4 & 18 & 1 & 7 & 303 & 20.46 \\
\hline
\end{tabular}

* Pos = seropositive; Neg = seronegative

The overall prevalence of anti-Toxocara $\mathrm{IgG}$ antibodies in male and female subjects was $22.65 \%(29 / 128)$ and $18.85 \%(33 / 175)$, respectively. The association between sex and positive serology in the population showed differences apparently not significant $($ Chi-square $=$ $0.66 ; \mathrm{OR}=1.26 ; \mathrm{p}=0.418)$. Nevertheless, a study about the repartition of frequencies of seropositivity according to the age groups showed a significant association in children from one to 10 years old by bivariate analysis $($ Chi-square $=4.47 ; \mathrm{OR}=1.85 ; \mathrm{p}=0.034)($ Table 2$)$

The community of Cullhuay (59 male and 71 female) showed a seroprevalence rate of $20.77 \%$ (27/130). From the subjects showing positive serology, $88.89 \%$ had titers of 200 , whereas only $11.11 \%$ had titers of 400 . The association between age and positive serology showed that subjects from 10 to 20 years old had a statistically significant association (Fisher's test, $\mathrm{p}=0.017$ ), with a high proportion in male subjects, whereas other age groups were statistically not significant. The communities of El Olivar (52 male and 68 female) and Lachaqui (17 male and 36 female) showed seroprevalence rates of $12.5 \%(15 / 120)$ and $37.73 \%(20 / 53)$, respectively. In the community of El Olivar, the $80 \%$ had titers of 200 whereas $20 \%$ had titers of 400 . In the community of Lachaqui, $70 \%$ had titers of 200 whereas $30 \%$ had titers of 400 . The association between age and positive serology showed differences statistically not significant in both communities.

The hematological analysis showed that $21.78 \%$ of the total population had low values of hemoglobin; the communities of Cullhuay, El Olivar and Lachaqui showed low values of hemoglobin at $7.69 \%$, $16.66 \%$, and $18.87 \%$, respectively. Furthermore, the microhematocrit test showed that $10.56 \%$ of the total population had low values of hematocrit; the communities of Cullhuay, El Olivar and Lachaqui showed low values of hematocrit at $5.38 \%, 15 \%$ and $13.2 \%$, respectively. The association between low values of hemoglobin or hematocrit with regard to the presence of positive serology showed differences that were not statistically significant (data not shown).

The population of Cullhuay showed a mean of total leukocytes of $7,891 \pm 1,034$ cells $/ \mu \mathrm{L}$ (range of 4,583 - 10,694 cells $/ \mu \mathrm{L}$ ), and a mean of eosinophils of $193 \pm 169.17$ cells $/ \mu \mathrm{L}$ (range of $0-1,069$ cells $/ \mu \mathrm{L}$ ). The population of El Olivar showed a mean of total leukocytes of 8,532 \pm 1206.56 cells $/ \mu \mathrm{L}$ (range of $5,972-10,723$ cells $/ \mu \mathrm{L}$ ), and a mean of eosinophils of $284 \pm 352.98$ cells $/ \mu \mathrm{L}$ (range of $0-1700$ cells $/ \mu \mathrm{L}$ ). The population of Lachaqui showed a mean of total leukocytes of 9,358 \pm 1764 cells/ $\mu \mathrm{L}$ (range of $6,944-14,500$ cells/ $\mu \mathrm{L}$ ), and the mean of eosinophils count was $375 \pm 316$ cells $/ \mu \mathrm{L}$ (range of 0 - 1402 cells $/ \mu \mathrm{L}$ ).

From the subjects with positive serology, $11.3 \%$ had leukocytosis and $14.51 \%$ had some type of eosinophilia $(8.06 \%$ had mild eosinophilia and $6.45 \%$ had moderate eosinophilia) whereas $11.2 \%$ of the subjects with negative serology had $11.2 \%$ leukocytosis and $14.52 \%$ had some type of eosinophilia (10.79\% had mild eosinophilia, and $3.73 \%$ had moderate eosinophilia), and their associations were statistically not significant (Chi-square $=0.00 ; \mathrm{p}=0.999 ; \mathrm{OR}=1.00)$. Moreover, the association between seropositivity and age for each community also was statistically not significant in any community (data not shown).

The clinical study showed that $38.7 \%$ of the seropositive group from the total population had at least some type of signs or symptoms in comparison with $16.18 \%$ found in the seronegative group. The most frequent clinical findings among the seropositive subjects were as follows: respiratory signs or symptoms (32.26\%), hepatic compromise $(22.58 \%)$, ocular signs or symptoms (17.74\%), neurological compromise $(9.68 \%)$, abdominal pain (14.51\%), and cutaneous signs (4.84\%), and all of them were statistically associated to positive serology by bivariate analysis $($ Chi-square $=15.20 ; \mathrm{p}=0.0001 ; \mathrm{OR}=3.27)($ Table 3$)$.

The parasitological analysis revealed that $87.45 \%$ (265/303) of the total population were parasitized. The communities of Cullhuay, El Olivar and Lachaqui were parasitized with rates of $79.23 \%, 93.3 \%$, and $94.3 \%$, respectively. From subjects with positive serology, $79.03 \%(49 / 62)$ had at least one intestinal parasite, and the pathogen protozoan parasites were as follows: Blastocystis hominis $76.24 \%$, Giardia lamblia $31.35 \%$ and Entamoeba histolytica/E. dispar $9.24 \%$. The helminth parasites were as follows: Hymenolepis nana $2.97 \%$, Trichuris trichiura $1.65 \%$ and Ascaris lumbricoides $1.32 \%$. The association between intestinal parasites and positive serology also revealed a significant association (Chi-square $=$ 5.05; $\mathrm{p}=0.0247 ; \mathrm{OR}=0.44)($ Table 3$)$.

Ownership of cats and/or dogs showed not significant association with seropositivity (Chi-square $=0.91 ; \mathrm{p}=0.471 ; \mathrm{OR}=2.64)$; however, their presence at home was significantly associated (Chi-square $=9.79$; $\mathrm{p}=0.010 ; \mathrm{OR}=9.01$ ). On the other hand, the use of public places (such as public parks or the central square of the community) by these people showed a significant association with the seropositivity (Chisquare $=6.66 ; \mathrm{p}=0.018 ; \mathrm{OR}=0.27$ ), as well as a previous history of pica or geophagia (Chi-square $=5.51 ; \mathrm{p}=0.018 ; \mathrm{OR}=$ Non applicable $)$ (Table 4). 
ESPINOZA, Y.A.; HUAPAYA, P.E.; ROLDÁN, W.H.; JIMÉNEZ, S.; ABANTO, E.P.; ROJAS, C.A.; CAVERO, Y.A. \& GUTIÉRREZ, C.A. - Seroprevalence of human toxocariasis in Andean communities from the northeast of Lima, Peru. Rev. Inst. Med. Trop. São Paulo, 52(1): 31-36, 2010.

Table 3

Distribution of clinical and laboratorial findings with regard to the serology for toxocariasis in three Andean communities from the province of Canta, Peru, 2007

\begin{tabular}{|c|c|c|c|c|c|c|c|c|}
\hline \multirow{2}{*}{$\begin{array}{l}\text { Clinical and } \\
\text { laboratorial } \\
\text { findings* }\end{array}$} & \multicolumn{4}{|c|}{ Anti-Toxocara $\operatorname{IgG}$ antibodies } & \multicolumn{2}{|c|}{ Bivariate analysis } & \multicolumn{2}{|c|}{ Multivariate analysis**** } \\
\hline & $\begin{array}{l}\text { Seropositive } \\
\quad(\mathrm{n}=62)\end{array}$ & $\%$ & $\begin{array}{c}\text { Seronegative } \\
(\mathrm{n}=241)\end{array}$ & $\%$ & $\mathrm{p}$ value** & OR $(95 \% \mathrm{CI})$ & $\mathrm{p}$ value & OR $(95 \% \mathrm{CI})$ \\
\hline Symptomatic (any) & 24 & 38.71 & 39 & 16.18 & $<0.001$ & $3.27(1.77-6.05)$ & & \\
\hline Anemia & 19 & 30.65 & 67 & 27.80 & 0.658 & $1.15(0.62-2.11)$ & & \\
\hline Eosinophilia & 8 & 12.90 & 35 & 14.52 & 0.744 & $0.87(0.38-1.99)$ & & \\
\hline Leukocytosis & 9 & 14.52 & 27 & 11.20 & 0.472 & $1.35(0.60-3.03)$ & & \\
\hline Intestinal parasites & 49 & 79.03 & 216 & 89.63 & 0.025 & $0.44(0.21-0.91)$ & 0.046 & $2.22(1.01-4.87)$ \\
\hline $\begin{array}{l}\text { Pulmonary } \\
\text { manifestations }\end{array}$ & 20 & 32.26 & 33 & 13.69 & 0.001 & $3.00(1.57-5.73)$ & 0.351 & $0.65(0.26-1.61)$ \\
\hline Hepatomegaly & 14 & 22.58 & 18 & 7.47 & 0.001 & $3.61(1.68-7.76)$ & 0.101 & $0.45(0.18-1.17)$ \\
\hline $\begin{array}{l}\text { Ocular } \\
\text { manifestations }\end{array}$ & 11 & 17.74 & 16 & 6.64 & 0.006 & $3.03(1.33-6.93)$ & 0.202 & $0.51(0.18-1.44)$ \\
\hline $\begin{array}{l}\text { Neurological } \\
\text { manifestations }\end{array}$ & 6 & 9.68 & 13 & 5.39 & 0.215 & $1.88(0.68-5.16)$ & & \\
\hline Abdominal pain & 9 & 14.52 & 19 & 7.88 & 0.108 & $1.98(0.85-4.63)$ & & \\
\hline $\begin{array}{l}\text { Cutaneous } \\
\text { manifestations }\end{array}$ & 3 & 4.84 & 10 & 4.15 & 0.811 & $1.17(0.31-4.40)$ & & \\
\hline
\end{tabular}

*Some subjects had more than one sign/symptom; **p $<0.05$ = significant value (Chi-square); *** variables in the model: sex, age, intestinal parasites, pulmonary manifestations, hepatomegaly, and ocular manifestations.

Table 4

Distribution of risk factors with regard to the serology for toxocariasis in three Andean communities from the province of Canta, Peru, 2007

\begin{tabular}{|c|c|c|c|c|c|c|c|c|}
\hline \multirow[t]{2}{*}{ Risk factors } & \multicolumn{4}{|c|}{ Anti-Toxocara IgG antibodies } & \multicolumn{2}{|c|}{ Bivariate analysis } & \multicolumn{2}{|c|}{ Multivariate analysis*** } \\
\hline & $\begin{array}{l}\text { Seropositive } \\
\quad(\mathrm{n}=62)\end{array}$ & $\%$ & $\begin{array}{l}\text { Seronegative } \\
(\mathrm{n}=241)\end{array}$ & $\%$ & $\mathrm{p}$ value $* *$ & OR $(95 \% \mathrm{CI})$ & $\mathrm{p}$ value & OR $(95 \% \mathrm{CI})$ \\
\hline $\begin{array}{l}\text { Ownership of } \\
\text { dogs and/or cats }\end{array}$ & 61 & 98.39 & 231 & 95.85 & $0.471^{\mathrm{a}}$ & $2.64(0.33-21.03)$ & & \\
\hline $\begin{array}{l}\text { Presence of pets } \\
\text { within the house }\end{array}$ & 61 & 98.39 & 210 & 87.14 & 0.010 & $9.01(1.21-67.32)$ & 0.061 & $0.14(0.02-1.09)$ \\
\hline $\begin{array}{l}\text { Use of public } \\
\text { places }\end{array}$ & 55 & 88.71 & 233 & 96.68 & $0.018^{\mathrm{a}}$ & $0.27(0.09-0.78)$ & 0.031 & $3.51(1.12-10.98)$ \\
\hline $\begin{array}{l}\text { History of pica or } \\
\text { geophagia }\end{array}$ & 62 & 100 & 221 & 91.70 & $0.018^{\mathrm{a}}$ & $\mathrm{NA}^{* *}$ & 0.998 & $\mathrm{NA}^{* *}$ \\
\hline
\end{tabular}

${ }^{*} \mathrm{p}<0.05=$ significant value; $* * \mathrm{NA}=$ Non applicable. ${ }^{\mathrm{a}}$ Fisher's exact test; $* * *$ variables in the model: sex, age, presence of pets within the house, use of public places, and history of pica or geophagia.

A multivariate regression analysis was accomplished with all the variables that were found significant at $\mathrm{p}<0.1$ by Chi-square test and then, adjusted by sex and age. This kind of analysis revealed that only 'intestinal parasites' $(\mathrm{p}=0.046 ; \mathrm{OR}=2.22)$ and the 'use of public places' $(\mathrm{p}=0.031 ; \mathrm{OR}=3.51)$ were found statistically significant among the groups of clinical data and risk factors, respectively.

\section{DISCUSSION}

Toxocariasis is considered a helminthic zoonosis of worldwide distribution and, until now, it is still an almost unknown disease among health professionals and the general population.
In the present study, we have observed an overall anti-Toxocara antibodies seroprevalence of $20.46 \%$ in inhabitants from three Andean communities of the province of Canta, Peru, with a higher significant proportion in children from one to 10 years old, suggesting that they were the main group in contact with the parasite. This value is relatively similar in comparison to other studies carried out in our country ${ }^{7,8}$ and

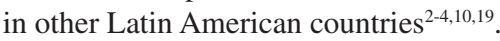

All the seropositive subjects had low titers of anti-Toxocara IgG antibodies, in comparison with high titers, which are usually found in cases of VLM, suggesting a contact with the parasite. Furthermore, we observed that the community of Lachaqui was the community with a 


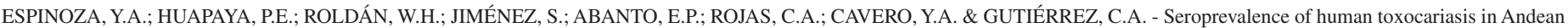
communities from the northeast of Lima, Peru. Rev. Inst. Med. Trop. São Paulo, 52(1): 31-36, 2010.

higher proportion of subjects infected by Toxocara larvae.

Many authors indicate that male subjects are usually more associated than female subjects with regard to a positive serology for toxocariasis, suggesting that male subjects might be at more risk to the infection, probably because of the closer contact with soil ${ }^{2-5,9,15,17}$, as is the case of this population, who are farmers or ranchers. However, we have found nonstatistically significant differences between gender and positive serology, contradicting the findings found by other authors above mentioned.

The majority of the studied population showed normal values of hemoglobin and only a small proportion of them showed low values of hemoglobin, suggesting that there are few possibilities of having anemia among the inhabitants of these three Andean communities.

Eosinophilia and leukocytosis were also present among the population and their frequencies were almost similar between seropositive and seronegative subjects, being also statistically not associated either with the serology or with the clinical findings, contradicting the idea from other authors that eosinophilia or leukocytosis might always be associated to Toxocara infections ${ }^{4,5,15}$. It is possible that in larval Toxocara infections, but not-toxocariasis cases, these types of clinical findings might not be present.

The highly significant association between signs/symptoms and positive serology indicates to us further evidence for Toxocara infection in this population $(\mathrm{p}<0.001)$ (Table 3$)$. Almost all of the clinical findings (with the exception of pulmonary compromise) evaluated in this study were apparently statistically significant with the serology, as obtained by bivariate analysis. Clinical findings such as hepatic, ocular, neurological and cutaneous manifestations, abdominal pain were more frequently found in seropositive children.

The presence of these signs/symptoms associated with a positive serology could indicate to us a possible case of toxocariasis, which is usually found in pediatric patients as reported by many authors ${ }^{5,9,15,17}$, but other clinical and laboratorial studies are necessary to be carried out in order to confirm these possible cases of human toxocariasis. MAGNAVAL et al. ${ }^{15}$ and PAWLOWSKI ${ }^{17}$ have referred that typical cases of VLM are not usually found in patients and it is possible that other different clinical forms of human toxocariasis, such as incomplete VLM or covert toxocariasis, might be more associated in patients with a previous history of geophagia or close contact with pets.

Ownership of dogs is very common in these families living in the field, as they use these animals to assist them with cattle, being considered very good work partners. However, ownership of dogs or cats apparently were not associated with the seropositivity in the present study ( $\mathrm{p}=$ 0.471 ), but when their presence within the houses was associated with the seropositivity, this association was statistically significant $(\mathrm{p}=0.002)$. It is possible that the true significance for risk of infection with Toxocara larvae might be the behavior of humans living together with their pets inside the houses. Many authors have stated that young pets or puppies are the main source of Toxocara eggs, ${ }^{5,15,17,27}$. Furthermore, CHIEFFI et $a l .{ }^{4}$ and WOLFE et $a{ }^{27}{ }^{27}$, reported a higher prevalence of infection in subjects who were in close contact with dogs.
The use of public places by people is another important risk factor associated to human toxocariasis, since canine feces are very frequent in public places and playgrounds in other countries ${ }^{1,4,5,15}$. Although limited studies about soil contamination with Toxocara eggs in Peru have revealed a prevalence ranging from $30 \%$ to $80 \%{ }^{13}$, this risk factor was significantly associated to Toxocara infection in this population in both bivariate $(\mathrm{p}=0.018)$ and multivariate $(\mathrm{p}=0.031)$ analysis. It is possible that this infection occurring in this population might have occurred by accidental ingestion of embryonated ova from the soil of public places within the communities. To ascertain this hypothesis, it will be necessary to undertake future studies about soil contamination with Toxocara eggs.

Geophagia (eating soil) is a specific type of pica that increases the risk of toxocariasis, especially in children living in homes with puppies that have not been dewormed, or children with a typical behavior of playing on the soil $1^{5,15}$. In this study, we have found that this type of human behavior is significantly associated to Toxocara infection $(\mathrm{p}=0.018)$. Moreover, geophagia is the main characteristic associated with human toxocariasis, as reported in several studies around the world since human toxocariasis has been described as a soil transmitted zoonosis ${ }^{2,5,13,15,17}$.

A high prevalence of intestinal parasites occasionally is found together with Toxocara infection and the statistical association between them might be closely related, as is the case of this population. As results show, more frequent parasites found in this population were protozoa and they do not cause cross-reactions with the ELISA test ${ }^{12,14,20}$. Nevertheless, these results suggest that this population might be exposed to a fecal contamination of food or poor hygiene, so this is another principal way to contract Toxocara infection in populations without a basic knowledge of personal hygiene.

The prevalence of human Toxocara infection found in the present study could be the result of various factors, but doubtless, the most important are the rural and social characteristics of the three communities of the province of Canta, a small Andean area in the Northeast of Lima city, with areas of unpaved streets and a deficient daily cleaning, with a high percentage of inhabitants with unsatisfactory basic needs and a relatively high proportion of dogs living at home. It is well known that when dogs live together with humans, within the house, the potential for household contamination with Toxocara eggs and the possibility of toxocariasis is high.

On the other hand, it is very interesting to note that the value of the seroprevalence found in this population is relatively similar to other previous studies with populations living in rural districts of Lima city, which has a low altitude above sea level and climatic conditions very different from the province of Canta. It is possible that other sources of contamination could be present there, such as domestic animals living together with the population. About this, some authors have mentioned the possibility of getting toxocariasis after eating raw or poorly cooked meat from some domestic animals such as chickens, pigs, sheep or cows ${ }^{6,15,22-24}$.

Serological and epidemiological characteristics for Toxocara infection were found in the present studied population. Future studies about soil contamination or canine toxocariasis should be performed to better assess the magnitude of this serious health problem, and community education programs should be developed to promote the social concept of responsible pet ownership. 
ESPINOZA, Y.A.; HUAPAYA, P.E.; ROLDÁN, W.H.; JIMÉNEZ, S.; ABANTO, E.P.; ROJAS, C.A.; CAVERO, Y.A. \& GUTIÉRREZ, C.A. - Seroprevalence of human toxocariasis in Andean communities from the northeast of Lima, Peru. Rev. Inst. Med. Trop. São Paulo, 52(1): 31-36, 2010.

We might conclude from our study that human toxocariasis is a parasitic zoonosis with a wide spectrum of unspecific clinical characteristics that, up to the present, has received little attention by the health community. Further studies will be required to ascertain the contribution of this helminthic zoonosis to the overall morbidity of such populations.

\section{RESUMO}

\section{Soroprevalência da toxocaríase humana em três comunidades andinas do Nordeste de Lima, Peru}

O propósito do presente trabalho foi estimar a soroprevalência da toxocaríase humana em três comunidades andinas do Nordeste de Lima, Peru. Foi estudado um total de 303 pessoas, entre crianças e adultos. Foram coletadas amostras de sangue para a detecção de anticorpos anti-Toxocara e para a análise hematológica, além de amostras fecais para o exame parasitológico. A soroprevalência geral da população foi de $20,46 \%$ com proporção significativamente maior de positividade em crianças de um a 10 anos $(\mathrm{p}=0,034)$. Das pessoas com sorologia positiva, $32,26 \%$ apresentavam sintomas respiratórios, $22,58 \%$ moléstias hepáticas, $17,74 \%$ manifestações oculares, 14,51\% dor abdominal, e $4,84 \%$ sinais cutâneos. Além disso, $79,03 \%$ das pessoas com sorologia positiva tinham pelo menos algum parasito intestinal com associação significativa $(\mathrm{p}<0.05)$. A presença de cachorros dentro das casas, história de pica ou geofagia e o uso dos lugares públicos também estiveram presentes nesta população, mas o ultimo deles só esteve associado com a sorologia positiva $(\mathrm{p}<0.05)$. Conclui-se que existem evidências clínicas, sorológicas e epidemiológicas de infecção por larvas de Toxocara na população estudada.

\section{REFERENCES}

1. Agudelo C, Villareal E, Cáceres E, López C, Eljach J, Ramírez N, et al. Human and dogs Toxocara canis infection in a poor neighborhood in Bogota. Mem Inst Oswaldo Cruz. 1990;85:75-8.

2. Alderete JM, Jacob CM, Pastorino AC, Elefant GR, Castro AP, Fomin AB, et al. Prevalence of Toxocara infection in schoolchildren from the Butantã region, São Paulo, Brazil. Mem Inst Oswaldo Cruz. 2003;98:593-7.

3. Alonso JM, Bojanich MV, Chamorro M, Gorodner JO. Toxocara seroprevalence in children from a subtropical city in Argentina. Rev Inst Med Trop Sao Paulo. 2000;42:235-7.

4. Chieffi PP, Ueda M, Camargo ED, de Souza AM, Guedes ML, Gerbi LJ, et al. Visceral larva migrans: a seroepidemiological survey in five municipalities of São Paulo state, Brazil. Rev Inst Med Trop Sao Paulo. 1990;32:204-10.

5. Despommier D. Toxocariasis: clinical aspects, epidemiology, medical ecology, and molecular aspects. Clin Microbiol Rev. 2003;16:265-72.

6. Deutz A, Fuchs K, Auer H, Kerbl U, Aspöck H, Köfer J. Toxocara-infestations in Austria: a study on the risk of infection of farmers, slaughterhouse staff, hunters and veterinarians. Parasitol Res. 2005;97:390-4.

7. Espinoza Y, Huapaya P, Sevilla C, Huiza, A. Toxocariosis humana: seroprevalencia en la población de Lima mediante la técnica de ELISA. An Fac Med (Perú). 2003;64:22832.

8. Espinoza Y, Huapaya P, Ayllón C, Sevilla C, Huiza A, Jimenez S. Toxocariosis humana en pacientes con lesión ocular. An Fac Med (Perú). 2003;64:247-51.
9. Espinoza YA, Huapaya PH, Roldán WH, Jiménez S, Arce Z, Lopez E. Clinical and serological evidence of Toxocara infection in school children from Morrope district, Lambayeque, Peru. Rev Inst Med Trop Sao Paulo. 2008;50:101-5.

10. Felix-Pífano CF, Orihuela AR, Delgado O, Cortez R, Abdul Hadi S, Dale de Ortíz M. La toxocariasis humana en Venezuela, especialmente en el valle de Caracas. Gac Méd Caracas. 1989;97:31-41.

11. Glickman L, Schantz P, Dombroske R, Cypess R. Evaluation of serodiagnostic test for visceral larva migrans. Am J Trop Med Hyg. 1978;27:492-8.

12. Jacquier $P$, Gottstein B, Stinlegin Y, Eckert J. Immunodiagnosis of toxocarosis in humans: evaluation of a new enzyme-linked immunosorbent assay kit. J Clin Microbiol. 1991;29:1831-5

13. Lescano SA, Chieffi PP, Peres BA, de Mello EO, Velarde CN, Salinas AA, et al. Soil contamination and human infection by Toxocara sp. in the urban area of Lima, Peru. Mem Inst Oswaldo Cruz. 1998;93:733-4.

14. Lynch NR, Eddy K, Hodgen AN, Lopez RI, Turner KJ. Seroprevalence of Toxocara canis infection in tropical Venezuela. Trans R Soc Trop Med Hyg. 1988;82:275-81.

15. Magnaval JF, Glickman LT, Dorchies P, Morassin B. Highlights of human toxocariasis. Korean J Parasitol. 2001;39:1-11.

16. Muñoz M, Morón C. Manual de procedimientos de laboratorio en técnicas Básicas de hematología (Serie de Normas Técnicas 40). Lima: Instituto Nacional de Salud; 2005.

17. Pawlowski Z. Toxocariasis in humans: clinical expression and treatment dilemma. J Helminthol. 2001;75:299-305

18. Portús M, Riera C, Prats G. A serological survey of toxocariasis in patients and healthy donors in Barcelona (Spain). Eur J Epidemiol. 1989;5:224-7.

19. Radman NE, Archelli SM, Fonrouge RD, del V Guardis M, Linzitto OR. Human toxocarosis. Its seroprevalence in the city of La Plata. Mem Inst Oswaldo Cruz. 2000;95:281-5.

20. Roldán W, Cornejo W, Espinoza Y. Evaluation of the dot-ELISA in comparison with standard ELISA for the immunodiagnosis of human toxocariasis. Mem Inst Oswaldo Cruz. 2006;101:71-4

21. Roldán WH, Espinoza YA, Atúncar A, Ortega E, Martinez A, Saravia M. Frequency of eosinophilia and risk factors and their association with Toxocara infection in schoolchildren during a health survey in the north of Lima, Peru. Rev Inst Med Trop Sao Paulo. 2008;50:273-8.

22. Sasmal NK, Acharya S, Laha R. Larval migration of Toxocara canis in piglets and transfer of larvae from infected porcine tissue to mice. J Helminthol. 2008;82:245-9.

23. Taira K, Saeed I, Permin A, Kapel CM. Zoonotic risk of Toxocara canis infection through consumption of pig or poultry viscera. Vet Parasitol. 2004;121:115-24.

24. Taira K, Permin A, Kapel CM. Establishment and migration pattern of Toxocara canis larvae in chickens. Parasitol Res. 2003;90:521-3.

25. Thompson DE, Bundy DA, Cooper ES, Schantz PM. Epidemiological characteristics of Toxocara canis zoonotic infection of children in a Caribbean community. Bull World Health Organ. 1986;64:283-90.

26. Williams WJ, Beutler E, Erslev AJ, Lichtman AM. Hematology. 4th ed. New York: Mc Graw-Hill; 1990 .

27. Wolfe A, Wright IP. Human toxocariasis and direct contact with dogs. Vet Rec. 2003;152:419-22.

Received: 21 March 2009

Accepted: 30 November 2009 